\title{
ENVIRONMENTAL COST AND FINANCIAL PERFORMANCE OF OIL AND GAS COMPANIES IN NIGERIA
}

\author{
Chiamogu, Anselm \\ Department of Accountancy, \\ Nnamdi Azikiwe University, Awka, Nigeria \\ $+2348062601677$ \\ Okoye, Janefrances $\mathbf{N}$. \\ Department of Entrepreneurship Studies, \\ Nnamdi Azikiwe University, Awka, Nigeria \\ Mail: janefrancesmakie@gmail.com
}

\begin{abstract}
This study ascertained the extent environmental cost affects financial performance of oil and gas companies in Nigeria. The specific objectives were to determine the effect of: community development cost and environmental remediation cost on Tobin's on oil and gas companies in Nigeria. Ex post facto research design was employed and data was obtained from annual reports and accounts for the periods 2011 to 2018. The hypotheses were tested using regression analysis with aid of e-view 9.0. The results of the empirical data analysis revealed that community development cost and environmental remediation cost has positive significant effect on Tobin's. The study therefore recommended among others that government should give tax credit to organizations that participate and contribute towards community development in order to encourage community development and which would go a long way in enhancing firm performance.
\end{abstract}

Keywords: Environmental Cost, Financial Performance, and Oil \& Gas Companies. 


\section{Introduction}

Environmental costs include costs of complying with environmental laws. It includes environmental remediation costs, pollution control equipment costs and non-compliance penalty. Based on the meaning of environmental degradation, environmental cost could also cover the cost incurred to prevent degradation, cost of re-stating the environment to its original state, cost of restoring depleted environment to its normal position (Okafor, 2018). Profit ascertainment requires the subtraction of recurrent costs from revenues. Most often, the costs that leads to changes in the environment, which affect people adversely and cause damages to the environment are not taken into consideration before profits are determined. In other words, the profits could be wrongly determined. The result of this, in most cases, is reporting of wrong and excessive profits which will also mislead the decision makers.

The environment has a long history of being regarded as unrelated to the economic system (Solomon \& Darby, 2005). Businesses for many decades have ignored the impact of their activities on the natural and social environment in which they operated, unless it had direct repercussions on the profit and loss account. Friedman (1970) famously supported this classical view of business objectives by stating that the sole reason for a firm's existence is to maximise the wealth of the shareholders, and that any act of philanthropy equates to stealing from the shareholders' wealth. Failure of a business to meet this fiduciary obligation was not only reprehensible but would result in sanctions such as a drop in share price or an enforced change of management (Friedman, 1970). However, the neglect by business of the negative externalities arising from the pursuit of economic objectives along with various environmental abuses by companies (e.g. Royal Dutch/Shell Brent Spar dumping and Ogoni crises in 1995 and British Petrochemical Gulf of Mexico rig explosion in 2010) have created less than positive attitudes amongst stakeholders towards business. Rodriguez and Cruz (2007) argued that customers are gradually altering their purchasing attitudes towards behaviours that are more sensitive to the natural and social environment. This then risks a tarnished image for those firms not taking environmental issues seriously. The politico-legal system has also undergone drastic transformation, directed at limiting the environmental degradation caused by business activities. For example, many world leaders have made specific commitments towards a phased reduction in carbon dioxide emissions. The United States is committed to cutting emission by 17 per cent in 2020, 30 per cent by 2025, 42 per cent by 2030 and 83 per cent by 2050. The United Kingdom is on course to meet its pledge to cut carbon dioxide levels by 34 per cent by 2020 and by 2050 to fulfil the target of an 80 per cent cut in greenhouse gases (Worthington, 2009). The United Nations conferences held in Copenhagen, Denmark in December 2009 and Durban, South Africa December 2011 are the most recent of the environmental summits reflecting this growing concern (Jacob, 2011).

Again businesses being partners in development and contributors to negative environmental impacts are expected to play lead role in instituting measures to mitigate their environmental impacts and achieve global reduction in negativities of their actions (Oliff \& Vandermerve, 2017) Peavler (2017) Gatimbu and Wabwire (2016) observed that businesses engaging in environmental management result in "win-win" situation and have better financial performance.

Despite the above observations some researchers such as Hossain, Islam and Andrew (2016) Agyapong and Nuertey (2017) strongly kicked against spending on the environment stating that businesses' expenditure on the environment affect businesses bottom line. Friedman (1970) claimed that environmental expenditure is a diversion of funds from positive projects 
thereby depriving shareholders of value for money, may increase price of customers and reduce employee wages.

In the light of the above contentions, empirical investigation of the effect of environmental costs on financial performance of oil and gas companies listed on the Nigeria Stock Exchange becomes inevitable hence this research work is carried out.

The main objective of this study was to ascertain the effect of environmental costs on financial performance of oil and gas companies listed on Nigeria stock exchange.

The specific objectives were to:

i. Ascertain the effect of Community Development Cost on Tobin's Q of Oil and Gas Companies listed on Nigeria Stock Exchange.

ii. Evaluate the effect of Environmental Remediation Cost on Tobin's Q of Oil and Gas Companies listed on Nigeria Stock Exchange.

\section{Review of Related Literature}

\section{Environmental Accounting in Nigeria}

Production activities within the environment have resulted to resources depletion and environmental degradation. These activities have further led to the depletion of ozone layer, thereby causing imbalance in the environmental system. Consequently, the increased concern about environmental degradation, resources depletion and the sustainability of economic activities has made Environmental Accounting and reporting an area of signification interest. In the recent times, in Nigeria, thus Environmental Accounting is a new concept that tries to recognize the side effects of production and consumption on the physical environment (Adediran \& Atu 2010). These effects of production and consumption should be recognized in the financial statements of organizations. In Nigeria, there are several statues regulating financial reporting of companies listed in the Nigeria Stock Exchange. Some of the statues are;-

1. Companies and Allied Matters Act 1990 as amended to date

2. Nigeria Accounting Standard Board (NASB), now Financial Reporting Council of Nigeria (FRCN)

3. Investment and Security Act 1999

4. Bank and other Financial Institutions Act 1991

5. The Insurance Act 1997

6. Security and Exchange Commission Law.

\section{Community Development Cost and Financial Performance}

Social responsibility encourages companies to balance social responsibilities and environmental responsibilities with profit. Consequently, profit maximization or a continuous market-share increase should be the main objective for companies (Badulescu, Badulescu, Saveanu, \& Hatos, 2018). As businesses evolve, other objectives keep on adding as well, to an ever-bigger extent, so as to lead to synergic effects. These objectives must also consider the effects of business decisions on stakeholders. The development of the relationship between companies, the state, and society, has led to an increase in the pressure on the business environment to make serious efforts to adopt and/or implement a wide range of CSR activities (Mensah, Agyapong \& Nuertey, 2017). The ever-growing interest in CSR has drawn the attention of researchers and of the business environment on its legitimacy and its 
effects on company performance. Stakeholders play an important role in the financial performance of a company (Sanchez-Hernandez, Gallardo-Vazquez, Barcik, Dziwinski, 2016). Thus, companies have adopted CSR practices in non-tax fields such as human rights, environmental protection, corporate contributions (sponsorships and philanthropic actions), local-community development, and workplace-related matters. Companies implementing CSR activities in their business strategy can strengthen clients' loyalty, boost the company image and reputation, offer a competitive advantage, and attract and maintain the best employees (Glavas \& Kelley, 2014). Thus, companies adopting CSR practices can increase their financial performance. Ionascu, Ionascu, Sacarin, Minu (2018) underlined that the only responsibility a company has is to increase shareholder wealth. Hategan, Sirghi, CureaPitorac and Hategan, (2018) argued that CSR only brings additional costs to the company, thus reducing shareholder wealth. Moreover, Chou, Chang, Darcy and Yan (2017) found a negative relation between community development cost and company financial performance (CFP).

\section{Environmental Remediation Cost and Financial Performance}

The performance of firms in terms of profitability largely depends on the nature of businesses they operate, and the possible legal, political and environmental regulations, which constitute an important item of public policy within the scope of their operation. The nature of business a firm operates defines the risks attached to such business and risk constitutes a significant factor in the profitability of the firm's operation. Higher financial risks constitute enormous treats to firms' profitability, though they are likely to attract huge amount of profits (Norhasimah, Norhabibi, Nor-Amiera, Sheh-Muhammad, Sheh \& Inaliah, 2016). The role of corporations in ensuring environmental sustainability has necessitated the need for a multidisciplinary approach to issues of environmental protection. While it is observed that environmental practices have often been perceived as the opportunity cost of economic growth, the ideology of sustainable development is beginning to dominate the sphere of public policy. The implication on corporate entities in this regard is to reconfigure their corporate objectives to reflect the same levels of environmental accountability. However, environmental disclosures are discretionary, suggesting that corporations exert unimaginable control over the preparation and disclosure of social and environmental information. Consequently, a disturbing effect is that in most cases, firms' claims of being environmentally responsible may simply reflect an attempt at corporate branding (Malarvizhi \& Ranjani, 2016; Karambu \& Joseph, 2016). According to Gallego-Alvarez (2012), little was recognized of the environmental depletion and degradation to the environment until a few well-meaning people in the developed countries realized that it was not good having great corporate profit without considering the cost of managing large scale of the ecosystem by which we are nourished. It became obvious that degradation, pollution and accelerated destruction of the ecosystem and the depletion of nonrenewable environment biodiversity have serious impact on the financial performance of firms. Danso and Adomako (2014) observed that companies in pursuit of profits can do great social harm and the environment suffers, thus, there is an emphasis for a meeting point between corporate objective of profit maximization and the need for environmental management. In this regard, the need for environmental cost has become the concern and focus of nations and responsible corporate managements (Van-Ewijk \& Stegemann, 2016). Scholars have done different works on the area of environmental remediation cost and firm performance and have obtained varying results. For instance, Amahalu, Okoye and Obi (2018); Okafor (2018); Li, Zheng, Cao, Chen, Ren \& Huang (2017) documented a positive relationship between environmental remediation cost and financial performance, while Bachmann and Ingenhoff (2016); Fosu, Danso, Ahmad 
and Coffie (2016) found a negative relationship between environmental remediation cost and financial performance.

\section{Empirical Review}

Earnhart and Lizal (2011) analyzed the effect of corporate environmental performance on financial performance in a transition economy of Czech. In particular, the study assessed whether good environmental performance affects profits, and if so, in which direction. The empirical results indicated strongly and robustly that better environmental performance improves profitability by driving down costs more than it drives down revenues. Cortez and Cudia (2011) explored the impact of environmental innovations on financial performance of Japanese electronics companies following the growing literature linking corporate social performance with profitability. Using sample electronics companies listed in the Tokyo Stock Exchange, the industry case study focused on the global manufacturing leaders as they play a significant role in advancing environmental reporting due to their supplier networks and subsidiaries. The findings pointed to risk minimization efforts of electronics companies in spite of declining profitability. Their sustainability performances are justified by the legitimacy granted to them as socially responsible that translates into improved revenue generation. Sjoerd, Nasser and Jolanda (2011) focused on the relationship between environmental sustainability and the financial performance of SMEs in terms of profit development and revenue development. The analysis used a unique dataset of 337 Dutch and Chinese firms using correlation and regression analysis. The results suggested a significant positive association between environmental sustainability and firm performance. Oti, Effiong and Tiesieh (2012) examined environmental costs and its implication on the returns on investment in Nigeria from 2001-2010. Data were collected from both primary and secondary sources and also analyzed using the ordinary least square technique. Findings from the empirical study disclosed a significant difference between the return on investment of the environmentally responsible firm and those of environmentally irresponsible firms. Arafat, Warokka and Dewi (2012) studied the effect of environmental performance on financial performance. The study analyzed 33 Indonesian manufacturing firms that were listed in Indonesian Stock Exchange (IDX) from 2005-2010 and reported their environmental performance assessment to the Ministry of Environment Indonesia. Statistic methods used for testing the hypothesis were T-test and multivariate regression model. The empirical results reveal that environmental performance has significantly influenced financial performance of the Indonesian manufacturing firm. Akabom (2012) carried out a study on the environmental friendly policies and their financial effects on corporate performance of selected oil and gas companies in Niger Delta Region of Nigeria. It was aimed at investigating if companies operating in the Niger Delta Region of Nigeria practice environmental accounting to the extent of inclusion of environmental friendly policies, and if so, how this affects the profitability of these companies. Data were collected from both primary and secondary sources. Thereafter, the data were analyzed using simple ordinary least square regression method and the study hypothesis was also validated. It was revealed that the cost of ensuring environmental friendly policies as well as firm competitiveness have significant relationship with the firms' profitability (Corporate performance). Olusegun (2012) explored the impact of corporate environmental responsibility on the financial performance in the extractive sector using a pooled secondary data of 101 multinational extractive companies for the period of 2008-2010 and primary data from a survey of 275 extractive sector managers. The results of this study showed that there is no relationship between corporate environmental responsibility and financial performance while the environmental attitude of managers is 
positively related to the perceived corporate reputation of their companies. Bessong and Tapang (2012) determined the influence of social responsibility cost on the profitability of Nigerian banks. The study made used of an exploratory research design and data were collected from five Nigerian banks through secondary sources and analyzed using the Ordinary Least Square (OLS) method. The study revealed that there is a negative influence between social cost and pollution cost on profitability. Phong, Hue and Thu (2012) studied the relationship between firm's environmental and financial performances in Vietnam's small and medium manufacturing firms by using the World Bank 2005 data on "Productivity and the Investment Climate". The analytical results indicated that better pollution control neither improves nor undermines financial success. SME_H group shows that high-inspected time standing for poor environmental performance has a statistically significant and positive impact on ROA standing for financial performance. Swinkels (2012) investigated the relation between the disclosure of a GRI sustainability report by companies and financial performance. The results of this study suggested there is no relation between the publication of a GRI sustainability report and financial performance in general. Also the study offered no evidence of a relation between a firm's application level of the GRI framework and guidelines and financial performance. Uadiale and Fagbemi (2012) focused on developing economies and on Nigeria specifically. Using a sample of forty audited financial statements of quoted companies in Nigeria from 2007-2011. The study examined the impact of CSR activities on financial performance measured with Return on Equity (ROE) and Return on Assets (ROA). The results showed that CSR has a positive and significant relationship with the financial performance measures. Ifurueze, Lyndon and Bingilar (2013) examined the impact of environmental cost on corporate performance in oil companies in the Niger Delta States of Nigeria. The field survey methodology was utilized involving a selected sample of twelve oil companies. The multiple regression analysis was explored to test the hypothesis. An investigation was undertaken into the possible relationship between corporate performance and three selected indicators of sustainable business practices: Community Development Cost (CDC), Waste Management Cost (WMC) and Employee Health and Safety Cost (EHSC). The study revealed that sustainable business practices and corporate performance is significantly related. And sustainability may be a possible tool for corporate conflict resolution as evidenced in the reduction of fines, penalties and compensations paid to host communities of oil companies. Therefore, the researchers recommended that the management of oil companies in the Niger Delta States of Nigeria develop a well articulated environmental costing system in order to guarantee a conflict free corporate atmosphere needed by managers and workers for maximum productivity and eventually improve corporate performance.

Makori and Jagongo (2013) established whether there is any significant relationship between environmental accounting and profitability of selected firms listed in India. The data for the study were collected from annual reports and accounts of 14 randomly selected quoted companies in Bombay Stock Exchange in India from 2006-2011. The data were analyzed using multiple regression models. The key findings of the study shows that there is significant negative relationship between Environmental Accounting and Return on Capital Employed (ROCE) and Earnings per Share (EPS) and a significant positive relationship between Environmental Accounting and Net Profit Margin and Dividend per Share. Based on this it was recommended that government should give tax credit to organizations that comply with its environmental laws and that environmental reporting should be made compulsory in India so as to improve the performance of organizations and the nation as a whole.

Mohammad, Sutrisno, Prihat \& Rosidi (2013) examined stakeholder theory and legitimacy as well as eco-efficient related to effect of environmental accounting implementation and environmental performance and environmental disclosure as mediation on company value. Samples are 59 selected companies in Indonesia from 2008-2012. Analysis technique used is 
the Partial Least Square (PLS). Research results indicated that environmental accounting implementation is able to affects company value, environmental accounting implementation effect on environmental information disclosure, environmental information disclosure effect on company value, environmental performance effect on company value, environmental performance effect on environmental information disclosure. However, environmental accounting implementation has not been able to affect company value through environmental information disclosure, as well as environmental performance has not been able to affect company value through environmental information disclosure.

Husser and Evraert-Bardinet (2014) looked at the relationship between market value, accounting fundamentals and companies' Corporate Social Responsibility (CSR) and Sustainable Development (SD) disclosures in France for the years 2007-2008. The multiple regression results showed that investors measure a company's short-term performance using information about the quality of the company's environmental management. At the same time, a company's social disclosure concerning the quality of employee management influences short and long-term performance. Gallego-_Alvarez, Segura and Martínez-Ferrero (2014) analyzed the impact of the variation in carbon dioxide emissions on financial and operational performance in Spain. By using international data consisting of 89 companies for the period 2006 - 2009, the findings showed a reduction in emissions that generates a positive impact on financial performance. Tze, Boon and Yee (2014) analysed the relationship between environmental improvement and the financial performance of firms on a sample of 78 leading companies listed in Bursa Malaysia. The study covered a period of 5 years, from 2008 to 2012. The study used content analysis to verify the extent of information disclosed and reported by companies. The results indicated there is a positive correlation between efficiency used towards natural resources and financial performance (both ROA and ROE). Bai, Pingli and Zhuang (2014) investigated the effect of multi-dimensional corporate environmental performance (CEP) on firm's financial performance and risk in Pakistan from 2005-2012. Considering two dimensions of CEP as environmental management performance (EMP) and environmental operational performance (EOP), the study found an inverted Ushaped relationship between carbon performance and Tobin's Q, and a positive relationship between EMP and Tobin's Q. The findings also provided evidences for the moderation effect of EMP on the EOP-Tobin's Q relationship. The study also found a significant positive relationship between the carbon performance and firm risk within manufacturing industries and an inverse relationship within service industries. Delmas, Nairn-Birch and Lim (2015) investigated the dynamics of environmental and financial performance: The case of greenhouse gas emissions (GGE). The study leveraged longitudinal data for 1,095 U.S. corporations from 2004 to 2008, a period of increasing activity for climate change legislation, in order to estimate the effect of greenhouse gas emissions on short- and long-term measures of financial performance. The study found that during this period, improving corporate environmental performance causes a decline in an indicator of short-term financial performance, return on assets. Nonetheless, investors see the potential long-term value of improved environmental performance, manifested by an increase in Tobin's q. Sarumpaet (2015) examined the relationship between environmental performance and financial performance amongst Indonesian companies. The environmental performance is measured by corporate environmental ratings provided by Bapedal/ the Ministry of Environment RI, through a program, called proper from 2006 to 2014, while the financial performance is measured by return on assets (ROA). Some control variables are also included in the regression analysis, namely: total sales, industry sector, stock exchange listing, and ISO 14001 certification. The study revealed while financial performance is not significantly 
associated with environmental performance, company size, stock exchange listing and ISO 14001 are significantly associated with environmental performance. Chang (2015) explored the impacts of environmental performance and propensity disclosure on financial performance using unbalanced panel data of eight heavy-pollution industries in China. Ezejiofor, John-Akamelu and Chigbo (2016) assessed the effect of sustainability accounting measure on the performance of corporate organizations in Nigeria from 2010-2015. Ex post facto research design and time series data were adopted. Data for study was collected from annual reports and accounts of the company in Nigeria. Formulated hypotheses were tested using Regression Analysis with aid of SPSS Version 20.0. Based on the analysis, the study found that environmental cost does not impact positively on revenue of corporate organizations in Nigeria, also that environmental cost impact positively on profit generation of corporate organizations in Nigeria. Based on this the researcher recommends that Indigenous and multi-national firms should ensure that strict policies as regards environmental accounting are adhered to, in order to enable stable organizational performance. Homan (2016) aimed to 1) determine how environmental accounting role in improving environmental performance and financial performance. The research method used is descriptive analysis. Based on the analysis founded empirically environmental accounting can improve environmental performance and financial performance. Most companies in Indonesia have ranked the environmental performance in the red category by PROPER in 2015. Disclosure of the environment has been done by most of the public companies in Indonesia less is implementing reporting environmental costs in the annual report 2015, especially in sub-sectors of tourism, hotels and restaurants. Bartolacci, Paolini, Soverchia and Zigiotti (2016) analysed the profitability of listed companies in Italy from 2009 to 2014. The empirical analysis using ordinary least square regression analysis was carried out on a population of 298 Italian companies. However, combining this information with that concerning separate waste collection, a clear relationship - both positive and negative - is not identifiable. Elias, Kostas and Dimitris (2016) examined the causal linkage between environmental and financial performance in Greek manufacturing firms from 2004-2014. These findings provide evidence that governmental and corporate actions are necessary in order to lead to a more sustainable corporate performance in the long run. Fahria, Sahibzada, and Abdul (2016) focused on assessing the impact of environmental reporting on the performances of the firms in the USA for the year 2015. The research has been undertaken onto the Manufacturing companies listed in the National Association of Securities Dealers Automated Quotations (NASDAQ). The study is a quantitative research with the adaptation of descriptive explanatory. It was found that environmental reporting positively impacts on the performance of the firms in the USA. Hilmi (2016) tested empirically, social performance and environmental performance to financial performance (relevant, accurate, timely and complete) to develop a theoretical framework as the basis for the hypothesis as an answer to the research question, namely, the extent to which manner: (1) the effects of social performance against the financial performance, (2) the effect on the environment performance to financial performance. Corporate social responsibility or Corporate Social Responsibility (CSR) is an idea that makes the company no longer faced with the responsibility that rests on a single bottom line is the value of the company is reflected in its financial condition, but the responsibility of the company should be based on the triple bottom lines which also pay attention to the dimensions of economic, social and environment that will guarantee the value of the company to grow in a sustainable manner. Pandey and Kumar (2016) confirmed whether there is any important connection between environmental cost incurred by companies in India and its profit earning ability. Based upon the sample data and its analysis using regression analysis, it has been found that there is no significant relationship between environmental 
expenditure of the company and its financial performance. Besides, it has also been found that companies with higher market capitalization are spending more on environmental issues. It is evident from the findings that environmental expenditure has no significant impact on profit earning ability of companies. Pariag-Maraye, Ansaram and Ramkalawon (2017) examined the relationship between environmental management practices adopted by listed firms on the Stock exchange of Mauritius and their impact, if any, on their financial performance. A content analysis of annual reports of the listed companies over the period 2011 to 2014 to determine the level of environmental management systems (EMS) was implemented by the local firms. The results found that companies tend to be more environmentally conscious due to compliance rather than a voluntary basis or to reap corporate benefits. Eilola (2017) examine the link between corporate environmental performance (CEP) and corporate financial performance (CFP) in the forest, paper and packaging industry and in the manufacturing of machinery and equipment industry. The study was conducted as a qualitative study although it includes also some quantitative elements. Data consisted of CEP disclosures, mainly corporate social responsibility reports and annual reports. Pearson's correlation coefficients were computed for CEP and CFP figure pairs. Differing from majority of earlier studies, this study indicates that there is no link between CEP and CFP - not from CEP to CFP nor CFP to CEP. The results indicated that companies are not punished for high environmental performance. Azomahou, Van \& Wagner (2017) examined the relationship between the environmental and economic performance of firms in the European paper manufacturing industry from 2011-2015. Hypotheses were tested using pooled regression and a panel regression framework with random firm and temporal effects. It was found that for the system with return on sales as economic performance variable, and an environmental performance index as environmental performance variable, a significant and positive regression coefficient was estimated for the asset-turnover ratio, as well as significant and negative coefficients for the dummy variables representing the industrial and mixed sub-sector. Hai, Foo, Tan \& Yap (2018) investigated the relationship between environmental disclosures and financial performance using a sample of potentially polluting publicly-listed companies in Singapore from 2012-2015. The issue was examined from several perspectives: (a) if there is any difference in financial performance between disclosing and non-disclosing companies of environmental information, (b) whether extent of environmental disclosure can be linked to financial performance, and (c) if there is any impact of prior financial performance on subsequent environmental disclosures, and viceversa. Results showed that a positive link existed although the evidence was less strong for the impact of environmental disclosures on subsequent financial performance. All null hypotheses were rejected. This finding should encourage Singapore companies to increase the content of their environmental reporting in annual reports. This is important in order to expose pollution-prone companies to a wider spectrum of stakeholders on their role to achieve a cleaner and greener environment. Nyirenda, Ngwakwe and Ambe (2018) examined the impact of environmental management practices on the financial performance of a South African mining firm. Using multiple regression statistics, the return on equity of Green-Steel is regressed on three environmental management practices of Green-Steel (carbon reduction, energy efficiency, and water usage). The result showed there is no significant relationship between the variables and this lends credence to information gathered from Green-Steel environmental reports that Green-Steel's environmental management practices are driven mostly by a desire to abide by regulations and also by a moral obligation to use environmental management practices to mitigate climate change impact. 
It becomes pertinent to empirically find out if negative or positive corporate environmental behaviour impact on firm financial performance. Some studies purport to find a positive relationship (Simerly 2018, Schaltegger \& Wagner, 2014; Coleman, 2011; Orlitzky, 2008; Rodriguez and Cruz, 2007; Salama, 2005). Similar studies found a negative relationship (Crane, Matten \& Moon, 2018; Bromley, 2016; Thornton, Kagan, \& Gunningham, 2013). While others showed either inconclusive results or (neutral) no effect (Klassen \& McLaughlin, 2016; Makni, Francoeur \& Bellavance, 2009), thereby creating a gap in knowledge.

\section{METHODOLOGY}

\section{Research Design}

The research design employed in this study is the ex-post facto research design, in order to establish a relationship between environmental cost and financial performance. This study was treated as ex-post facto research since it relied on historical data. This is appropriate because ex-post facto research aims at measuring and establishing the relationship between one variable and another or the effect of one variable on another, in which the variables involved are not manipulated by the researcher (Kothari \& Garg, 2014).

\section{Population of the Study}

The population of this study consist of all the of eleven (11) oil and gas companies listed on the Nigerian Stock Exchange as at $31^{\text {st }}$ December, 2018. They include; Japaul Oil \& Maritime Services Plc, Oando Plc, Beco Petroleum Products Plc, Capital Oil Plc, Conoil Plc, Rak Unity Petroleum Plc, Eterna Plc, Forte Oil Plc, Mobil Oil Plc, MRS Oil Nigeria Plc and Total Nigeria Plc.

\section{Sample Size and Sampling Method}

The entire eleven (11) Oil and Gas companies were selected as the sample size of this study with the utilization of purposive sampling method. Data were gathered from the published financial statements of the eleven (11) Oil and Gas companies for eleven (11) years period spanning from 2008-2018, using Purposive sampling method (that is all the Oil and Gas firms that filed their annual financial statements with NSE from 2008-2018 without missing any year were selected for this study). The reason for the choice of this time frame is availability of published annual report and accounts of the selected organizations and to have a fairly, reasonably, reliably and up-to-date available financial data.

\section{Method of Data Analysis}

The data analysis for the study took the form of descriptive statistics and inferential statistics. This research work adopted the panel least square (PLS) regression analysis with longitudinal (panel) regression using E-Views 9.0 statistical software. The reason for adopting panel data regression is because of the number of Oil and Gas firms and the period of time involved (Koutsoyiannis, 2001).

\section{Panel Data Regression Analysis}

Panel data involves the pooling of observations on a cross-section of units over several time periods and provides result that is simply not detectable in pure cross section or pure time series. According to Hsiao (2009), such data increases the explanatory power of the model. The regression technique used in this study is to determine the effect of environmental cost on financial performance. There are two benefits of using panel data model if it is compared with using only time series and cross section (Nelson, 2006 \& Hsiao, 2009). First, combining time series and cross- section data in panel data makes the total of observations bigger. 
Panel data model is described below:

$\mathrm{Y}_{\mathrm{it}}=\beta_{1}+\beta_{2} X_{\mathrm{it}}+\varepsilon_{\mathrm{it}}$

Where:

$\mathrm{Y}=$ dependent variable

$\mathrm{X}=$ all the independent variables

$\beta 1=$ the constant term

$\beta_{2}=$ slope/coefficient of the independent variable

$\varepsilon=$ error term

$\mathrm{i}=(1,2,3 \ldots, 11)-$ number of Oil and Gas firms

$\mathrm{t}=(1,2,3 \ldots, 11)-$ number of years

$i \mathrm{x} t=(11 * 11)$

Panel data is better in identifying and measuring the effects of a cross section of behaviours. This is often combined with time series to arrive at results which only cross-section or time series data cannot provide.

In Panel data; fixed and random effect models take the one-way error component method. The choice of using any of them depends on the significance of the Hausman test (TorresReyar, 2009). In this study, a Hausman test will be used to determine the more consistent method between the fixed effect model and the random effect model.

\subsubsection{Fixed Effect Model (FEM)}

FEM appears when there is the individual effect and explanatory variables have a correlation with $\mathrm{X}_{\mathrm{it}}$ or have a pattern that nature is not random. This assumption makes an error component of the individual, and time effects can be part of the interception.

\subsubsection{Random Effect Model (REM)}

REM appears when there is the individual effects and no correlation among regressors. This assumption makes an error component of the individual and time effects included in the error.

\subsubsection{Hausman Test}

In choosing this is better between the fixed or random effect, the Hausman test will be used in this study. The hypothesis is stated as:

$\mathrm{H} 0: \mathrm{E}($ i $\mathrm{xit})=0$ or REM is the correct model

H1: $\mathrm{E}($ Ki $\mathrm{xit})=0$ or FEM is the correct model

Ki $=$ firms error term

Xit $=$ independent variable 


\subsubsection{Co-efficient of Correlation}

This is a good measure of relationship between two variables, tells us about the strength of relationship and the direction of relationship as well.

\section{Model Specification}

The following research models were formulated in line with the research hypotheses in order to empirically determine the effect of environmental cost on financial performance.
$\mathrm{TQ}_{\mathrm{it}}=$
$\beta_{0}+\beta_{1} \mathrm{CDC}_{\mathrm{it}}+\beta_{2} \mathrm{FSZ}_{\mathrm{it}}+\beta_{3} \mathrm{LEV}_{\mathrm{it}}+\mu_{\mathrm{it}}$
Model i
$\mathrm{TQ}_{\mathrm{it}}=$
$\beta_{0}+\beta_{1} \mathrm{ERC}_{\mathrm{it}}+\beta_{2} \mathrm{FSZ}_{\mathrm{it}}+\beta_{3} \mathrm{LEV}_{\mathrm{it}}+\mu_{\mathrm{it}}$
Model ii

\section{Legend:}

$\mathrm{TQ}_{\mathrm{it}}=$ Tobin's $\mathrm{Q}$ of firm $i$ in period $t$

$\mathrm{CDC}_{\mathrm{it}}=$ Community Development Cost of firm $i$ in period $t$

$\mathrm{ERC}_{\mathrm{it}}=$ Environmental Remediation Cost of firm $i$ in period $t$

$\mathrm{FSZ}_{\mathrm{it}}=$ Firm Size of firm $i$ in period $t$

$\mathrm{LEV}_{\mathrm{it}}=$ Leverage of firm $i$ in period $t$

$\mu_{i, t}=$ component of unobserved error term of firm $i$ in period $t$

$\beta_{0}=$ constant term

$\beta_{1}, \beta_{2}$ and $\beta_{3}=$ are slopes to be estimated of firm $i$ in period $t$.

$i=$ firm identifier (11 firms)

$\mathrm{t}=$ time variable $(2008,2009, \ldots . .2018)-($ Eleven Years $)$

\section{Decision Rule:}

Accept $\mathrm{H}_{0}$, if the P-value of the test is greater than 0.05 , otherwise reject.

\section{DATA PRESENTATION AND ANALYSIS}

\section{Table 1 Descriptive Statistics}

$\begin{array}{cccccc} & \text { TQ } & \text { CDC } & \text { ERC } & \text { FSZ } & \text { LEV } \\ \text { Mean } & 0.361 & 0.199 & 0.675 & 10.952 & 9.116 \\ \text { Median } & 0.210 & 0.170 & 0.730 & 10.830 & 8.880 \\ \text { Maximum } & 1.230 & 0.670 & 0.910 & 12.020 & 10.450 \\ \text { Minimum } & 0.030 & 0.050 & 0.370 & 9.930 & 7.250 \\ \text { Std. Dev. } & 0.347 & 0.164 & 0.186 & 0.789 & 1.005 \\ \text { Skewness } & 1.611 & 2.336 & -0.493 & 0.011 & -0.179 \\ \text { Kurtosis } & 4.632 & 7.525 & 2.078 & 1.507 & 2.167 \\ \text { Jarque-Bera } & 5.979 & 19.392 & 0.835 & 1.022 & 0.376 \\ \text { Probability } & 0.050 & 0.000 & 0.659 & 0.600 & 0.828 \\ \text { Sum } & 3.970 & 2.190 & 7.420 & 120.470 & 100.280 \\ \text { Sum Sq. Dev. } & 1.201 & 0.270 & 0.345 & 6.229 & 10.094 \\ \text { Observations } & 121 & 121 & 121 & 121 & 121\end{array}$

Source: E-Views 9.0 Descriptive Output, 2019 


\section{Interpretation}

Table 1 presents the descriptive statistics for the different variables of the study with an observation of 121 (i.e 11 firms x 11 years). Mean is the most commonly used measure of central tendency. The standard deviation shows the deviation/dispersion/variation from the mean. It is a measure of risk, the higher the standard deviation, the higher the risk. The standard deviation is a measure that summarizes the amount by which every value within a dataset varies from the mean. It is the most robust and widely used measure of dispersion. Skewness indicates the symmetry of the distribution. A skewed distribution which is positive indicates scores that are clustered to the left, and the tail of the distribution extending to the right while a negatively skewed distribution demonstrates scores that are clustered to the right and the tail of the distribution extends to the left. Kurtosis on the other hand, defines the peak of the distribution. Positive kurtosis is indicated by a peak. Negative kurtosis is indicated by a flat distribution. The data set in table 4.1 shows a mean and standard deviation for: TQ = 0.361 and $0.347 ; \mathrm{CDC}=0.199$ and $0.164 ; \mathrm{ERC}=0.675$ and $0.186 ; \mathrm{FSZ}=10.952$ and 0.789 ; $\mathrm{LEV}=9.116$ and 1.005 suggesting a skewed distribution. Concerning the normality tests; skewness and kurtosis of the models were analyzed.

\section{Table 2: Pearson Correlation Matrix}

$\begin{array}{cccccc} & \text { TQ } & \text { CDC } & \text { ERC } & \text { FSZ } & \text { LEV } \\ \text { TQ } & 1.000 & -0.316 & 0.548 & 0.011 & -0.036 \\ \text { EHSC } & 0.031 & -0.083 & 0.066 & -0.394 & -0.454 \\ \text { WMC } & 0.356 & 0.068 & 0.522 & -0.741 & -0.605 \\ \text { CDC } & -0.316 & 1.000 & 0.131 & -0.004 & -0.096 \\ \text { ERC } & 0.548 & 0.131 & 1.000 & -0.550 & -0.466 \\ \text { CC } & 0.302 & -0.360 & -0.568 & 0.595 & 0.553 \\ \text { FSZ } & 0.011 & -0.004 & -0.550 & 1.000 & 0.934 \\ \text { LEV } & -0.036 & -0.096 & -0.466 & 0.934 & 1.000\end{array}$

Source: E-Views 9.0 Correlation Output, 2019

\section{Interpretation of Pearson Correlation Matrix}

The result of the Pearson correlation result in table 1 reports that there is a positive correlation between ERC, FSZ and TQ as indicated by the coefficient factors of 0.548, $0.302,0.011$ respectively, while LEV negatively correlate with TQ.

\section{Test of Hypotheses}

\section{Test of Hypothesis 1}

Ho: : Community Development Cost has no significant effect on Tobin's Q of Oil and Gas Companies listed on Nigeria Stock Exchange.

$\mathbf{H}_{1}$ : Community Development Cost has significant effect on Tobin's Q of Oil and Gas Companies listed on Nigeria Stock Exchange. 
Table 3: Panel Least Square Regression Analysis between Community Development Cost and Tobin's $Q$ of listed Oil and Gas Companies

Dependent Variable: TQ

Method: Panel Least Squares

Date: 09/03/19 Time: 17:19

Sample: 20082018

Periods included: 11

Cross-sections included: 11

Total panel (balanced) observations: 121

\begin{tabular}{lrlrr}
\hline \hline \multicolumn{1}{c}{ Variable } & Coefficient & \multicolumn{1}{c}{ Std. Error } & t-Statistic & Prob. \\
\hline \hline C & 0.057948 & 0.733904 & 0.078959 & 0.9372 \\
CDC & 0.515852 & 0.259006 & 2.991659 & 0.0009 \\
FSZ & 0.133058 & 0.169263 & 4.786099 & 0.0000 \\
LEV & -0.130548 & 0.160848 & -4.811624 & 0.0000 \\
\hline \hline R-squared & 0.534613 & Mean dependent var & 0.493763 \\
Adjusted R-squared & 0.509860 & S.D. dependent var & 0.845262 \\
S.E. of regression & 0.841084 & Akaike info criterion & 2.524250 \\
Sum squared resid & 82.76850 & Schwarz criterion & 2.616673 \\
Log likelihood & -148.7171 & Hannan-Quinn criter. & 2.561786 \\
F-statistic & 31.38307 & Durbin-Watson stat & 1.112146 \\
Prob(F-statistic) & 0.000000 & & \\
\hline \hline
\end{tabular}

E-Views 9.0 Regression Output, 2019

The relationship estimated for the model is shown thus:

$\mathrm{TQ}=0.057948+0.515852 \mathrm{CDC}+0.133058 \mathrm{FSZ}-0.130548 \mathrm{LEV}$

The model shows that CDC, FSZ, LEV significantly affect listed oil and gas companies' performance as measured by TQ. The results also indicate that, CDC, FSZ and LEV are all significant at 5\% level of significance. This result implies that the more the Nigerian oil and gas companies spent money on community development, the better their performance. Serial correlation is proved to be absent based on the Durbin-Waston statistic result of 1.112146. Based on the analysis results therefore, this study rejects the hypothesis that community development cost has no significant effect on the performance of Nigerian listed oil and gas companies. Moreover, the model summary of the regression results shows the combined effect of CDC, FSZ and LEV variables on the financial performance of Nigerian listed oil and gas companies as shown by the Prob(F-statistic) $=0.000000$, to be statistically significant at $5 \%$ level. The combined $\mathrm{R}^{2}$ which is the coefficient of determination is 0.51 . This means that $51 \%$ of the performance of Nigerian listed oil and gas companies is explained by CDC, FSZ and LEV while the remaining $49 \%$ is explained by other factors outside the model.

\section{Decision}

Going by the empirical deduction, which reports that $\operatorname{Prob}(\mathrm{F}$-statistic) $=0.000000$ is less than the critical P-value of 0.05 , thus, $\mathrm{H}_{1}$ is accepted and Ho is rejected. The implication of this result is that Community Development Cost has significant positive effect on Tobin's Q of Oil and Gas Companies listed on Nigeria Stock Exchange at 5\% level of significance. 


\section{Table 4: Fixed Effect Model between CDC, FSZ, LEV and TQ}

Dependent Variable: TQ

Method: Panel Least Squares

Date: 09/03/19 Time: 17:20

Sample: 20082018

Periods included: 11

Cross-sections included: 11

Total panel (balanced) observations: 121

\begin{tabular}{crrrr}
\hline \hline Variable & Coefficient & Std. Error & t-Statistic & Prob. \\
\hline \hline C & 1.085540 & 0.932247 & 1.164434 & 0.2468 \\
CDC & 0.497281 & 0.316666 & 2.570365 & 0.0085 \\
FSZ & 0.070984 & 0.183423 & 0.386994 & 0.6995 \\
LEV & -0.166438 & 0.169816 & -2.980106 & 0.0009 \\
\hline \hline
\end{tabular}

Effects Specification

Cross-section fixed (dummy variables)

\begin{tabular}{lrll}
\hline \hline R-squared & 0.200420 & Mean dependent var & 0.493763 \\
Adjusted R-squared & 0.163275 & S.D. dependent var & 0.845262 \\
S.E. of regression & 0.800425 & Akaike info criterion & 2.501096 \\
Sum squared resid & 68.55284 & Schwarz criterion & 2.824576 \\
Log likelihood & -137.3163 & Hannan-Quinn criter. & 2.632474 \\
F-statistic & 8.063099 & Durbin-Watson stat & 1.297242 \\
Prob(F-statistic) & 0.000018 & & \\
\hline \hline
\end{tabular}

E-Views 9.0 Regression Output, 2019 


\section{Table 5: Random Effect Model between CDC, FSZ, LEV and TQ}

Method: Panel EGLS (Cross-section random effects)

Date: 09/03/19 Time: 17:20

Sample: 20082018

Periods included: 11

Cross-sections included: 11

Total panel (balanced) observations: 121

Swamy and Arora estimator of component variances

\begin{tabular}{|c|c|c|c|c|}
\hline Variable & Coefficient & Std. Error & t-Statistic & Prob. \\
\hline $\mathrm{C}$ & 0.541048 & 0.822745 & 0.657613 & 0.5121 \\
\hline $\mathrm{CDC}$ & 0.513045 & 0.283596 & 2.809068 & 0.0066 \\
\hline FSZ & 0.106119 & 0.173179 & 0.612770 & 0.5412 \\
\hline LEV & -0.150295 & 0.162602 & -0.924312 & 0.3572 \\
\hline \multicolumn{5}{|c|}{ Effects Specification } \\
\hline & & & S.D. & Rho \\
\hline Cross-section random & & & 0.311423 & 0.1315 \\
\hline Idiosyncratic random & & & 0.800425 & 0.8685 \\
\hline \multicolumn{5}{|c|}{ Weighted Statistics } \\
\hline R-squared & 0.034433 & \multirow{5}{*}{\multicolumn{2}{|c|}{$\begin{array}{l}\text { Mean dependent var } \\
\text { S.D. dependent var } \\
\text { Sum squared resid } \\
\text { Durbin-Watson stat }\end{array}$}} & 0.302453 \\
\hline Adjusted R-squared & 0.009674 & & & 0.800309 \\
\hline S.E. of regression & 0.796428 & & & 74.21284 \\
\hline F-statistic & 2.390760 & & & 1.219408 \\
\hline $\operatorname{Prob}($ F-statistic) & 0.029103 & & & \\
\hline \multicolumn{5}{|c|}{ Unweighted Statistics } \\
\hline R-squared & 0.029769 & Mean dependent var & & 0.493763 \\
\hline Sum squared resid & 83.18381 & Durbin-Watson stat & & 1.087900 \\
\hline
\end{tabular}

E-Views 9.0 Regression Output, 2019

\section{Table 6: Hausman Specification Test}

Correlated Random Effects - Hausman Test

Equation: Untitled

Test cross-section random effects

\begin{tabular}{lrrr}
\hline \hline Test Summary & Chi-Sq. Statistic & Chi-Sq. d.f. & Prob. \\
\hline \hline Cross-section random & 10.834346 & 3 & 0.0222 \\
\hline \hline
\end{tabular}

E-Views 9.0 Output, 2019

\section{Interpretation of Post Regression Analysis}

Based on the result of the Hausman specification test in table 6, the p-value of the test is 0.0222 , which is statistically significant at the conventional level of 0.05 . Thus, the Fixed Effect Model (FEM) is preferred over the Random Effect Model (REM) in analyzing the 
effect of Community Development Cost on Tobin's Q of Oil and Gas Companies listed on Nigeria Stock Exchange at 5\% level of significance.

\section{Test of Hypothesis 2}

Ho2: Environmental Remediation Cost has no significant effect on Tobin's Q of Oil and Gas Companies listed on Nigeria Stock Exchange.

$\mathbf{H}_{2}$ : Environmental Remediation Cost has significant effect on Tobin's Q of Oil and Gas Companies listed on Nigeria Stock Exchange.

\section{Table 5: Panel Least Square Regression Analysis between Environmental Remediation Cost and Tobin's $Q$ of listed Oil and Gas Companies}

\begin{tabular}{|c|c|c|c|c|}
\hline \multicolumn{5}{|c|}{$\begin{array}{l}\text { Dependent Variable: TQ } \\
\text { Method: Panel Least Squares } \\
\text { Date: 09/03/19 Time: } 17: 22 \\
\text { Sample: } 20082018 \\
\text { Periods included: } 11 \\
\text { Cross-sections included: } 11 \\
\text { Total panel (balanced) observations: } 121\end{array}$} \\
\hline Variable & Coefficient & Std. Error & $\mathrm{t}$-Statistic & Prob. \\
\hline $\mathrm{C}$ & 0.405255 & 0.725111 & 5.558888 & 0.0000 \\
\hline ERC & 0.014913 & 0.261830 & 8.056956 & 0.0000 \\
\hline FSZ & 0.072754 & 0.169513 & 6.429193 & 0.0000 \\
\hline LEV & -0.074918 & 0.161549 & -0.463750 & 0.6437 \\
\hline R-squared & 0.711911 & \multicolumn{2}{|c|}{ Mean dependent var } & 0.493763 \\
\hline $\begin{array}{l}\text { Adjusted R- } \\
\text { squared }\end{array}$ & 0.623681 & \multicolumn{2}{|c|}{ S.D. dependent var } & 0.845262 \\
\hline S.E. of regression & 0.855212 & \multicolumn{2}{|c|}{ Akaike info criterion } & 2.557563 \\
\hline Sum squared resid & 85.57227 & \multicolumn{2}{|c|}{ Schwarz criterion } & 2.649986 \\
\hline Log likelihood & -150.7326 & \multirow{2}{*}{\multicolumn{2}{|c|}{$\begin{array}{l}\text { Hannan-Quinn criter. } \\
\text { Durbin-Watson stat }\end{array}$}} & 2.595100 \\
\hline F-statistic & 24.74661 & & & 0.985170 \\
\hline Prob(F-statistic) & 0.000000 & & \\
\hline
\end{tabular}

E-Views 9.0 Regression Output, 2019

\section{Interpretation of Regression Result}

Table 7 shows the empirical effect of Environmental Remediation Cost on Tobin's Q of oil and gas companies in Nigeria. The Beta Coefficient value for the variables reveal that: ERC $\left(\beta_{1}\right)=0.014913 ;$ FSZ $\left(\beta_{2}\right)=0.072754 ;$ LEV $\left(\beta_{3}\right)=-0.074918$. The slope coefficient; $\mathrm{P}\left(\mathrm{x}_{\mathrm{i}}=0.0000 ; \mathrm{x}_{2}=0.0000 ; \mathrm{x}_{3}=0.6437\right)$. Using the $\mathrm{T}$ - Ratio to test for their statistical significance, it was found that ERC and FSZ variables are statistically significant at $5 \%$ level. This is due to the fact that their observed T-values are positive and above the "rule of thumb of 2". The other variable (LEV) is statistically non-significant because the observed t-value is either negative or far less than the 'rule of thumb' of 2. However, the empirical results show that ERC, FSZ, LEV accounts for $62.4 \%$ of the changes in Tobin's Q while $37.6 \%$ are attributed to other factors apart from ERC, FSZ, LEV. The F-statistic $=24.74661$ with its associated Prob(F-statistic) $=0.000000$ implies that the overall joint effect of ERC, FSZ, and LEV on Tobin's Q is statistically significant at $5 \%$ level. 
The estimated relationship equation of the model is:

$\mathrm{TQ}=0.405255+0.014913 \mathrm{ERC}+\mu$

The implication is that, for there to be a unit/one naira increase in TQ there will be 0.014913 increase in ERC, holding other factors constant.

\section{Decision}

Going by the rule of thumb, $\mathrm{H}_{1}$ is accepted while Ho is rejected, since the P-value of the equation is 0.000000 which is less than the critical value of $0.05(5 \%)$. This implies that Environmental Remediation Cost has a significant positive effect on Tobin's Q at 5\% level of significance.

\section{Table 8: Fixed Effect Model between ERC, FSZ, LEV and TQ}

Dependent Variable: TQ

Method: Panel Least Squares

Date: 09/03/19 Time: 17:22

Sample: 20082018

Periods included: 11

Cross-sections included: 11

Total panel (balanced) observations: 121

\begin{tabular}{|c|c|c|c|c|}
\hline Variable & Coefficient & Std. Error & $\mathrm{t}$-Statistic & Prob. \\
\hline $\mathrm{C}$ & 1.777414 & 0.907218 & 3.959191 & 0.0003 \\
\hline ERC & 0.391486 & 0.300336 & 6.303491 & 0.0000 \\
\hline FSZ & 0.009909 & 0.176271 & 5.056213 & 0.0000 \\
\hline LEV & -0.096207 & 0.164642 & -0.584340 & 0.5602 \\
\hline \multicolumn{5}{|c|}{ Effects Specification } \\
\hline \multicolumn{5}{|c|}{ Cross-section fixed (dummy variables) } \\
\hline & \multicolumn{4}{|c|}{ Mean } \\
\hline R-squared & \multicolumn{4}{|c|}{$\begin{array}{l}\text { 0.594779 dependent var } \\
\text { S.D. dependent }\end{array}$} \\
\hline Adjusted R-squared & \multicolumn{3}{|c|}{0.546948 var } & 0.845262 \\
\hline S.E. of regression & \multicolumn{3}{|c|}{$\begin{array}{l}0.803244 \text { criterion } \\
\text { Schwarz }\end{array}$} & 2.508127 \\
\hline Sum squared resid & \multicolumn{3}{|c|}{$\begin{array}{l}\text { 69.03654 criterion } \\
\text { Hannan-Quinn }\end{array}$} & 2.831607 \\
\hline Log likelihood & \multicolumn{3}{|c|}{-137.7417 criter. } & 2.639505 \\
\hline F-statistic & \multicolumn{3}{|c|}{21.90977 stat } & 1.228395 \\
\hline Prob(F-statistic) & \multicolumn{3}{|c|}{0.000000} & \\
\hline
\end{tabular}

E-Views 9.0 Output, 2019 


\section{Table 9: Random Effect Model between ERC, FSZ, LEV and TQ}

Dependent Variable: TQ

Method: Panel EGLS (Cross-section random effects)

Date: 09/03/19 Time: 17:23

Sample: 20082018

Periods included: 11

Cross-sections included: 11

Total panel (balanced) observations: 121

Swamy and Arora estimator of component variances

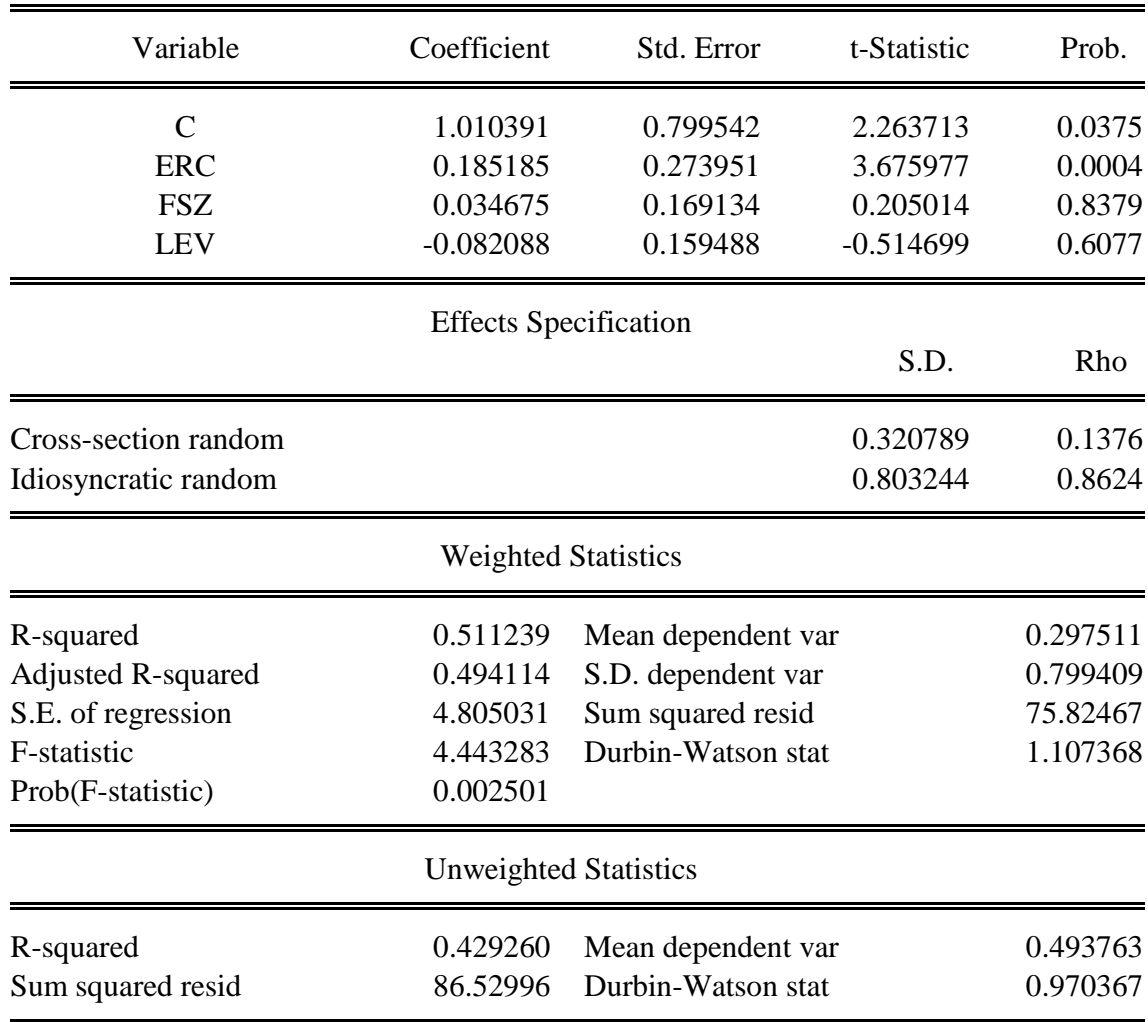

E-Views 9.0 Output, 2019

\section{Table 10: Hausman Specification Test}

Correlated Random Effects - Hausman Test

Equation: Untitled

Test cross-section random effects

\begin{tabular}{lrrr}
\hline \hline Test Summary & Chi-Sq. Statistic & Chi-Sq. d.f. & Prob. \\
\hline \hline Cross-section random & 10.520961 & 3 & 0.0246 \\
\hline \hline
\end{tabular}

E-Views 9.0 Output, 2019

\section{Interpretation of Post Regression Analysis}

Based on the result of the Hausman specification test in table 10, the p-value of the test is 0.0246 , which is statistically significant at the conventional level of 0.05 . Thus, the Fixed Effect Model (FEM) is preferred over the Random Effect Model (REM) in analyzing the 
effect of Environmental Remediation Cost on Tobin's Q of Oil and Gas Companies listed on Nigeria Stock Exchange at 5\% level of significance.

\section{Discussion of Findings}

This study ascertained the affect of environmental cost on financial performance of listed oil and gas firms in Nigeria during the period 2008-2018.

The model for hypotheses 1 showed that CDC, FSZ, LEV significantly affect listed oil and gas companies' performance as measured by TQ. The results also indicate that, CDC, FSZ and LEV are all significant at 5\% level of significance. This result implies that the more the Nigerian oil and gas companies spent money on community development, the better their performance. Serial correlation is proved to be absent based on the Durbin-Waston statistic result of 1.112146. Based on the analysis results therefore, this study rejects the hypothesis that community development cost has no significant effect on the performance of Nigerian listed oil and gas companies. Moreover, the model summary of the regression results shows the combined effect of CDC, FSZ and LEV variables on the financial performance of Nigerian listed oil and gas companies as shown by the Prob(F-statistic) $=0.000000$, to be statistically significant at $5 \%$ level. The combined $\mathrm{R}^{2}$ which is the coefficient of determination is 0.51 . This means that $51 \%$ of the performance of Nigerian listed oil and gas companies is explained by CDC, FSZ and LEV while the remaining $49 \%$ is explained by other factors outside the model.

The Beta Coefficient value for the variables in hypothesis 2 revealed that: ERC $\left(\beta_{1}\right)=$ 0.014913; FSZ $\left(\beta_{2}\right)=0.072754$; LEV $\left(\beta_{3}\right)=-0.074918$. The slope coefficient; $\mathrm{P}\left(\mathrm{x}_{\mathrm{i}}=0.0000\right.$; $\left.\mathrm{x}_{2}=0.0000 ; \mathrm{x}_{3}=0.6437\right)$. Using the $\mathrm{T}$ - Ratio to test for their statistical significance, it was found that ERC and FSZ variables are statistically significant at 5\% level. This is due to the fact that their observed T- values are positive and above the "rule of thumb of 2". The other variable (LEV) is statistically non-significant because the observed t-value is either negative or far less than the 'rule of thumb' of 2. However, the empirical results show that ERC, FSZ, LEV accounts for $62.4 \%$ of the changes in Tobin's Q while $37.6 \%$ are attributed to other factors apart from ERC, FSZ, LEV. The F-statistic $=24.74661$ with its associated Prob(Fstatistic) $=0.000000$ implies that the overall joint effect of ERC, FSZ, and LEV on Tobin's $\mathrm{Q}$ is statistically significant at $5 \%$ level.

\section{Conclusion}

This study examined the effect of environmental costs on financial performance of oil and gas companies listed on Nigeria stock exchange from 2008-2018 periods. Panel data were sourced from the annual reports and accounts of the sampled oil and gas firms. Descriptive statistics were adopted to describe the mean, standard deviation, kutosis and skewness of the study variables, while inferential statistics using correlation analysis, panel least square regression, and hausman test were employed via E-Views 9.0 statistical software. Data analysis revealed that a significant relationship exists between environmental costs and financial performance of listed oils and gas firms in Nigeria. As disaggregated components, Community Development Cost and Environmental Remediation Cost exerted a significant positive effect on Tobin's Q. Consequently, this analysis supports growing evidence that environmental costs have a significant relationship and exerts significant effect on financial performance at 5\% significant level. The study further concludes that the components of environmental costs considered in this study are important variables in explaining financial performance of listed oil and gas firms in Nigeria. 


\section{Recommendations}

The following recommendations were made in line with the findings and conclusion of this study:

i. Government should give tax credit to organizations that participate and contribute towards community development in order to encourage community development and which would go a long way in enhancing firm performance.

ii. Since Environmental Remediation Cost and financial performance are positively related, then oil and gas firms should be environmentally friendly to enable them gain competitive advantage, high liquidity and reduced environmental cost in the long run. 


\section{REFERENCES}

Adediran, S.A., \& Atu, O.K. (2010). Corporate environmental responsibility as a means of alleviating Niger Delta Crises. Academic Scholarship Journal 2(1), 46-61.

Akabom, I.A. (2012). Environmental friendly policies and their financial effects on corporate performance of selected oil and gas companies in Niger Delta region of Nigeria. American International Journal of Contemporary Research, 2(1), 168-173.

Arafat, M.Y., Warokka, A., \& Dewi, S.R. (2012). Does environmental performance really matter? A lesson from the debate of environmental disclosure and firm performance. Journal of Organizational Management Studies, 1(1), 1-15.

Azomahou, T., Van, P.N., \& Wagner, M. (2017). Determinants of environmental and economic performance of firms: An empirical analysis of the European paper industry, International Summer School on .Economics, Innovation, Technological Progress, and Environmental Policy., Seeon (Bavaria), 8-12 September 2011, 1-70.

Bachmann, P., Ingenhoff, D. (2016). Legitimacy through CSR disclosures? The advantage outweighs the disadvantages. Public Relat. Rev. ,42, 386-394.

Badulescu, A., Badulescu, D., Saveanu, T., \& Hatos, R. (2018). The relationship between firm size and age, and its social responsibility actions-focus on a developing country (Romania). Sustainability, 10, 805.

Bessong, P.K., \& Tapang, A.T. (2012). Social responsibility cost and its influence on the profitability of Nigerian banks. International Journal of Financial Research, 3(4), 33 45 .

Chang (2015). The impacts of environmental performance and propensity disclosure on financial performance: Empirical evidence from unbalanced panel data of heavypollution industries in China. Journal of Industrial Engineering and Management, 8(1), 21-36.

Chou, L.C., Chang, T.C., Darcy, J., \& Yan, Y.C. (2017). The impact of social responsibility on corporate performance: Evidence from Taiwan. Account. Financ. Res. 6, 181-189.

Cortez, M.A., \& Cudia, C.P. (2011).Sustainability and firm performance: A case study of Japanese electronics companies. Ritsumeikan International Affairs,.10, 321-340.

Danso, A., \& Adomako, S. (2014). The financing behaviour of firms and financial crisis. Manag. Financ., 40,1159-1174.

Earnhart, D., \& Lizal, L. (2011). The effect of corporate environmental performance on financial outcomes - profits, revenues, and costs: Evidence from the Czech transition economy. Paper presented at the DIME Final Conference, 6-8 April 2011, Maastricht, 1-43.

Eilola, M. (2017). The link between corporate environmental performance and corporate financial performance. Master's thesis submitted to Jyväskylä University School of Business and Economics, 1-67.

Ezejiofor, R.A., John-Akamelu, R.C., Chigbo, B.E. (2016). Effect of sustainability environmental cost accounting on financial performance of Nigerian corporate 
organizations. International Journal of scientific research and management (IJSRM) 4(08), 4536-4549.

Friedman, M. (1970). The social responsibility of business is to increase its profits. The New York Times Magazine,13, 32-33.

Gallego-Alvarez, I. (2012). Impact of CO2 emission variation on firm performance. Bus. Strategy Environ. 21, 435-454.

Gatimbu, K.K., \& Wabwire, J.M. (2016). Effect of corporate environmental disclosure on financial performance of firms listed at Nairobi securities exchange, Kenya. International Journal of Sustainability Management and Information Technologies, 2(1), 1-6.

Glavas, A., \& Kelley, K. (2014). The effects of perceived corporate social responsibility on employee attitudes. Bus. Ethics Q, 24, 165-202.

Goldenberg, (2009). Copenhagen climate change talk must fail, says top scientist. Available at: http://www.guardian.co.uk/environment/2009/dec/02/copenhagen-climate-jameshansen [Accessed December 05 2009].

Hai, Y.T., Foo, W.P., Tan, T.J., \& Yap, Y.L. (2018). Environmental disclosures-financial performance link: Further evidence from industrialising economy perspective. Nanyang Business School, Nanyang Technological University, Singapore, 1-28.

Hategan, C.D., Sirghi, N., Curea-Pitorac, R.I., \& Hategan, V.P. (2018). Doing well or doing good: The relationship between corporate social responsibility and profit in Romanian Companies. Sustainability, 10, 1041.

Hossain, M., Islam, K., \& Andrew, J. (2016). Corporate social and environmental disclosure in developing countries: Evidence from Bangladesh. Asian Pacific Conference. University of Wollongong.

Ionascu, M., Ionascu, I., Sacarin, M., Minu, M. (2018). Women on boards and financial performance: Evidence from a European emerging market. Sustainability, 10, 1644.

Jacob, M. (2011). Hope at last at the Durban conference on climate change. The Guardian. Available at: http://www.guardian.co.uk/commentisfree/2011/dec/11/durbanconference-climate-change. [Accessed 15 January 2012].

Li, D., Zheng, M., Cao, C., Chen, X.. Ren, S., \& Huang, M. (2017). The impact of legitimacy pressure and corporate profitability on green innovation: Evidence from China top 100. J. Clean. Prod., 141, 41-49.

Malarvizhi, P., \& Ranjani, M. (2016). Link between corporate environmental disclosure and firm performance. Perception or reality? Review of Integrated Business \& Economic Research, 5(3), 34-47.

Mensah, H.K., Agyapong, A., \& Nuertey, D. (2017). The effect of corporate social responsibility on organizational commitment of employees of rural and community banks in Ghana. Cogent. Bus. Manag. 4, 1-19. 
Norhasimah, M.N., Norhabibi, A. S., Nor-Amiera, A., Sheh-Muhammad, Q. A. Sheh, K., \& Inaliah, M. A. (2016). The effects of environmental disclosure on financial performance in Malaysia. Procedia \& Economics and Finance 35(4), 117-126.

Nyirenda, G., Ngwakwe, C.C., \& Ambe, C.M. (2018). Environmental management practices and firm performance in a South African mining firm. Managing Global Transitions $11(3), 243-260$.

Okafor, T.G. (2018).Environmental costs accounting and reporting on firm financial performance: A survey of quoted Nigerian oil companies. International Journal of Finance and Accounting, 7(1), 1-6.

Oliff, M. D., \& Vandermerwe, S. (2017). Customers drive corporations green. Long Range Planning, 23 (6), 10-17.

Olusegun, M.V. (2012). The impact of corporate environmental responsibility on financial performance: Perspective from the multinational extractive sector. A thesis submitted to Brunel Business School, Brunel University.

Oti, P.A., Effiong, S.A., \& Tiesieh, T.A. (2012). Environmental costs and its implication on the returns on investment: An evaluation of selected manufacturing companies in Nigeria. Global Journal of Management and Business Research, 12(7), 1-5.

Pariag-Maraye, N., Ansaram, K., \& Ramkalawon, N.D. (2017). Environmental management systems and financial performance: The case of listed companies in Mauritius. Scientific Research, 7(7), 1-14.

Peavler, R. (2017). Market to book financial ratio. https://www.thebalance.com/what-is-themarket-to-book-financial-ratio-393212. retrieved 13/3/2017

Phong, T.H., Hue, C.T., \& Thu, H.N. (2012). Impact of firm's environmental performance on its financial performance: Empirical evidence from Vietnam's small and medium manufacturing firms. 2012 JSPS Asian CORE Program, Nagoya University and VNU University of Economics and Business, 1-18.

Rodriguez, F.J., \& Cruz, Y.M. (2007), Relationship between social-environmental responsibility and performance in hotel firms. Hospitality Management, 26, 824-839.

Sanchez-Hernandez, M.I., Gallardo-Vazquez, D., Barcik, A., Dziwinski, P. (2016). The effect of the internal side of social responsibility on firm competitive success in the business services industry. Sustainability, 8, 179.

Sjoerd, V., Nasser, B., \& Jolanda, H. (2011). Environmental sustainability and financial performance of SMEs. Scales, Scientific Analysis of Entrepreneurship and SMEs, 147.

Solomon, J. F., \& Darby, L. (2005). Is private social, ethical and environmental reporting mythicizing or demythologizing reality? Accounting Forum, 29, 27-47.

Worthington, B. (2009). What do the US and China's emission target actually mean? Available at http://www.guardian.co.uk/environment/cif-green/2009/nov/26/us-chinatarget-mean [Accessed December 4th 2009]. 